\title{
REAKSI PASAR MODAL INDONESIA TERHADAP PERISTIWA POLITIK
}

\author{
Yosi Stefhani \\ *)Dosen Tetap Program S1 Jurusan Manajemen Fakultas Ekonomi Universitas Satya Negara Indonesia \\ Jalan Arteri Pondok Indah No.11 Jakarta Selatan \\ Email: yosi.stefhani@yahoo.com
}

Jurusan Manajemen, Fakultas Ekonomi, Universitas Satya Negara Indonesia

\begin{abstract}
The purpose of this research is to see how the Indonesian capital market reacts to political events. The political event referred to in this study was the election of the President. Capital market reaction can be seen from the presence or absence of differences in abnormal returns before and after the presidential election. The sample in this study companies included in the $L Q$ 45 index during the presidential election period. The presidential election itself was held on April 17, 2019. Observations were made 10 days before the presidential election and 10 days after the presidential election. The data analysis method used is the paired sample $t$ test. The results showed that there were no differences in abnormal returns before and after the election event. The results of this study indicate that the capital market does not react to these political events.
\end{abstract}

\section{PENDAHULUAN}

Analisa sekuritas terdiri dari analisa fundamental dan analisa teknik. Analisa fundamental sendiri terdiri dari analisa ekonomi, analisa industri dan analisa perusahaan. Analisa ekonomi dilakukan dengan memperhatikan faktor-faktor makro yang mampu mempengaruhi kinerja perusahaan. Sementara itu kondisi perekonomian itu sendiri tidak hanya dipengaruhi dari aspek ekonomi tapi bisa jadi dari aspek lain seperti aspek politik. Aspek politik dengan ekonomi pada saat ini sudah menjadi dua aspek yang saling berkaitan. Sebagai gambaran investor yang akan berinvestasi di suatu Negara memperhatikan kondisi politik Negara tersebut untuk memastikan kelancaran berinvestasi bagi investor. Sekarang banyak Negara karena kondisi politik yang tidak kondusif berpengaruh terhadap kondisi perekonomiannya.

Indikator perekonomian suatu Negara salah satunya bisa dilihat dari kinerja pasar modalnya. Secara teoritis berbagai peristiwa politik mampu mempengaruhi kinerja pasar modal karena peristiwa tersebut lebih tepatnya mempengaruhi keputusan investor yang berinvestasi di pasar modal. Hal ini disebabkan peristiwa politik menjadi salah satu informasi yang dipertimbangkan ketika seorang investor akan berberinvestasi di pasar modal. Contohnya saja proses peralihan pemerintah secara umum memberikan gambaran kepada para investor terkait ketidakpastian kondisi perekonomian Negara tersebut. Hal 
ini disebabkan jika terjadi pergantian pemerintahan berpotensi akan merubah kebijakan ekonomi yang baru. Masa transisi ketidakpastian pergantian pemerintahan akan memberikan signal ketidakpastian bagi para investor sehingga investor akan sangat berhati-hati ketika akan membuat keputusan investasi. Masa transisi ketidakpastian pergantian pemerintahan biasa terjadi di peristiwa politik seperti pada masa pemilihan umum presiden.

Sebagai gambaran beberapa peristiwa politik mampu mempengaruhi kondisi perekonomian berdasarkan beberapa penilitian yang telah dilakukan. Penelitian yang dilakukan oleh Amos Alogo Nainggolan tahun 2010 terkait pergantian pemerintahan di Indonesia, Malaysia ,Thailand dan bagaimana peristiwa-peristiwa politik berpengaruh terhadap kondisi perekonomiannya. Indikator kondisi perekonomian yang digunakan dalam penelitian tersebut adalah integrasi pasar modal negara-negara tersebut. Hasil penelitiannya menunjukan bahwa peristiwa politik mampu mempengaruhi integrasi pasar modal Negara-negara tersebut baik dalam jangka pendek dan jangka panjang. Penelitian lainnya yang dilakukan oleh Ima Kristina Yulita (2017) terkait peristiwa politik lainnya yaitu peristiwa pengumuman keputusan investasi Raja Salman. Bagaimana dampak peristiwa tersebut terhadap pasar modal Indonesia. Hasil penelitian menunjukan bahwa peristiwa tersebut direspon oleh pasar modal secara positif . ini menunjukan investor menilai peristiwa tersebut akan membuat prospek perekonomian menjadi lebih baik kedepan. Sementara peristiwa politik lainnya juga bisa berdampak negatif terhadap pasar modal. Penelitian yang dilakukan oleh Penelitian yang dilakukan oleh Murdifi, Nur Hidayati dan Juanidi (2018) terkait peritiwa politik penetapan vonis Ahok tanggal 9 Mei 2017. Peristiwa ini memberikan dampak yang negatif terhadap pasar modal ini menunjukan investor bereaksi terhadap peristiwa tersebut dan memandang informasi peristiwa tersebut negatif. Hasil penelitian-penelitian tersebut memperkuat teori yang menyatakan bahwa informasi terkait berbagai peristiwa politik dapat berpengaruh terhadap kinerja pasar modal. Oleh karena itu peneliti tertarik untuk mengambil penelitian dengan judul "Reaksi Pasar Modal Indonesia Terhadap Peristiwa Politik".

\section{Perumusan Masalah}

Permasalahan dalam penelitin ini dibatasi hanya satu peristiwa politik yaitu pemilihan umum Presiden Republik Indonesia tanggal 17 April 2019. Sehingga perumusan masalah dalam penelitian ini "bagaimana reaksi pasar modal Indonesia terhadap peristiwa pemilihan umum Presiden Republik Indonesia"?

\section{KERANGKA PEMIKIRAN TEORITIS}

Pasar modal adalah pasar yang memperjualbelikan surat berharga jangka panjang. Surat berharga yang dimaksud diantaranya adalah obligasi dan saham. Saham merupakan surat berharga yang berbentuk penyertaan/kepemillikan sehingga pemilik saham merupakan pemilik dari penerbit saham tersebut. Obligasi dan saham bisa diterbitkan oleh perusahaan atau pemerintah. 
Sementara itu keuntungan yang bisa diperoleh oleh investor ketika berinvestasi disaham adalah (1) dividen dan (2) capital gain. Dividen merupakan laba yang diperoleh perusahaan kemudian dibagikan kepada pemegang saham. Keuntungan lainnya yang adalah berbentuk capital gain. Capital gain merupakan keuntungan yang berasal dari selisih harga jual dan harga beli dimana harga jual saham lebih tinggi dibandingkan harga beli saham. Jika harga jual saham lebih rendah dibandingkan harga beli saham maka disebut sebagai capital loss (kerugian). Saham merupakan surat berharga yang paling popular di pasar modal.

Indeks saham merupakan informasi penting bagi para investor di pasar modal. Informasi ini menjadi salah satu pertimbangan investor dalam membuat keputusan melakukan transaksi atau tidak. Indeks harga saham adalah indikator yang menunjukan pergerakan harga saham dan berfungsi sebagai indikator tren pasar. Ini berarti indeks harga saham bisa menggambarkan kondisi pasar apakah sedang aktif atau lesu. Secara teoritis ada 5 fungsi indeks :

1. Sebagai indikator tren pasar

2. Sebagai indikator tingkat keuntungan

3. Sebagai tolak ukur (benchmark) kinerja suatu portfolio

4. Memfasilitasi pembentukan portfolio dengan strategi pasif

5. Memfasilitasi berkembangnya produk derivatif.

\section{Analisa Sekuritas}

Analisa sekuritas pada umumnya dilakukan seorang investor pada saat akan membuat keputusan berinvestasi atau tidak di pasar modal. Analisa sekuritas terdiri dari analisa fundamental dan analisa teknikal. Analisa Fundamental merupakan analisa sekuritas yang dilakukan secara top down mulai dari (1) analisa ekonomi, (2) analisa industri dan (3) analisa perusahaan.

Analisa ekonomi melihat faktor-faktor makro ekonomi yang mampu mempengaruhi kinerja seluruh perusahaan. Tujuan analisa ekonomia adalah membuat keputusan investasi dana di beberapa Negara atau keputusan investasi dana apakah dalam bentuk saham, obligasi ataupun kas. Analisa industri investor mencoba membandingkan kinerja berbagai industri untuk bisa mengetahui jenis industri mana yang memberikan prospek paling menjanjikan. Analisa perusahaan analisa yang dilakukan untuk menilai apakah sekuritas yang dikeluarkan menguntungkan atau merugikan bagi investor. Analisa ini dilakukan setelah kita menentukan akan di industri mana kita berinvestasi maka kemaudian analisa perusahaan akan menentukan sekuritas mana yang akan dipilih.

Analisa teknikal adalah teknik untuk memprediksi arah pergerakan harga saham dan indikator pasar saham lainnya berdasarkan pada data pasar historis seperti informasi harga dan volume. Analisa teknikal juga didefinisikan sebagai studi terhadap suatu sekuritas atau pasar secara keseluruhan berdasarkan permintaan dan penawaran. Data historis harga dan aktivitas volume transaksi diolah terutama dalam bentuk chart untuk meramalkan trend harga masa depan. 


\section{Faktor Lain Yang Mempengaruhi Keputusan Berinvestasi Di Pasar Modal}

Selain melakukan analisa sekuritas diatas maka ketika investor akan berinvestasi akan mempertimbangkan informasi atau faktor lainnya. faktor lainnya lebih tepat dikategorikan sebagai faktor non ekonomi, diantaranya :

1. Stabilitas politik. Stabilitas politik sangat penting untuk diperhatikan karena terkait kepastian dan keamanan kondisi suatu Negara atau wilayah. Politik yang tidak stabil berpotensi menyebabkan ketidakpastian dan kerusuhan sangat berpotensi terjadi di suatu Negara atau wilayah yang kondisi politiknya tidak stabil.

2. Penegakan hukum. Tidak adanya kepastian hukum akan menyebabkan berpotensi membuat para investor malas berinvestasi karena khawatir ketidakpastian hukum di masa yang akan datang jika terjadi sesuatu yang berhubungan dengan hokum.

3. Kondisi tenaga kerja di Negara atau wilayah yang bersangkutan. Masalah ketenagakerjaan di suatu Negara atau wilayah menjadi penting karena kondisi ini akan mendukung perekonomian Negara atau wilayah tersebut. Kondisi tenaga kerja yang tidak baik akan berpotensi menyebabkan ketidaksatabilan keamanan karena berpotensi memunculkan masalah seperti demonstrasi dan yang lainnya.

4. Sistem administrasi yang sederhana, cepat dan professional. Sistem administrasi dalam hal ini misalnya saja berkaitan dengan kemudahan dalam berinvestasi atau berusaha di suatu Negara atau wilayah. Prosedurial yang sederhana, cepat dan dan professional jelas akan menstimulus investor untuk berinvestasi.

Salah satu faktor non ekonomi yang dipertimbangkan ketika investor berinvestasi di pasar modal adalah kestabilan politik. Kestabilan politik biasanya ditandai dengan ada peristiwa politik yang terjadi. Peristiwa politik yang menjadi perhatian atau melibatkan masyarakat secara umum biasanya mampu mempengaruhi kestabilan politik suatu Negara atau wilayah. Jika kemudian peristiwa politik direspon positif oleh masyarakat makan akan menciptakan suasana politik yang kondusif. Suasana politik yang kondusif akan mendorong para investor untuk berinvestasi karena tidak ada kekhawatiran akan kondisi politik kedepan. Tetapi jika peristiwa politik tersebut direspon negatif oleh masyarakat pada umumnya maka akan menyebabkan kondisi politik yang kurang kondusif dan ini tidak akan mendorong investor untuk berinvestasi. Tetapi ada juga peristiwa politik yang menyebabkan ketidakjelaskan suasana politik. Kondisi ketidakjelasan seperti ini biasanya terjadi pada peristiwa politik tertentu contohnya saja pemilihan umum presiden. Peristiwa politik yang dimaksud adalah masa pemilihan umum presiden bukan peristiwa politik seperti pengumuman presiden baru atau pemerintahan baru. Ketidakjelasan disebabkan masih dalam masa periode pemilihan umum presiden sehingga kepastian presiden terpilih belum ada dan masyarakat pada umumnya akan menunggu kepastian tersebut. Termasuk juga investor yang akan berinvestasi pada pasar modal. Masa pemilihan umum presiden merupakan masa dimana investor menunggu kepastian akan hasil pemilihan umum untuk menentukan keputusan investasi apa yang akan dilakukan. 
Untuk melihat dampak suatu peristiwa terhadap pasar modal bisa dilihat dari respon investor. Salah satu indikator repson investor bisa dilihat dari abnormal return. Abnormal return merupakan selisih antara actual return dan expected return. Actual return merupakan return realisasi atau return yang memang terjadi. Sementara expected return merupakan return yang diharapkan oleh investor. Expected return ditentukan berdasarkan persepsi investor dan seluruh informasi yang dimiliki oleh informasi. Bagaimana kemudian investor berdasarkan persepsi dan informasi yang dia miliki menentukan expected returnnya. Jika pasar dan para investor memiliki informasi yang sama maka berpotensi akan menyebabkan respon yang sama antara pasar dan investor. Respon pasar sendiri bisa dilihat dari actual return. Sehingga jika antara actual return dan expected return sama atau tidak jauh beda dengan kata lain abnormal return 0 atau kecil menunjukan respon yang sama antara pasar dan investor. Tapi jika tidak maka akan ada abnormal return yang tinggi. Pada dasarnya abnormal return berpotensi ada karena pada umumnya expected return tidak selalu akan sama persis dengan actual return, hanya besaran yang kemudian menunjukan apakah ada perbedaan respon antara pasar dan investor. Sehingga melihat dampak suatu peristiwa bisa dilihat dari dengan cara apakah kemudian ada perbedaan antara abnormal return sebelum dan sesudah secara signifikan.

Berbagai penelitian terdahulu yang relevan terkait reaksi pasar modal terhadap peristiwa politik telah dilakukan, diantaranya penelitian-penelitian berikut ini :

1. Penelitian lainnya yang dilakukan oleh Ima Kristina Yulita (2017) dengan judul "Reaksi Pasar Modal Terhadap Pengumuman Keputusan Investasi Raja Salman di Indonesia". Penelitian ini meneliti apakah terdapat abnormal return sebagai indikator reaksi pasar pada hari-hari menjelang pengumuman keputusan investasi Salman King. Sampel yang digunakan adalah 95 perusahaan yang terdaftar dalam Indeks Kompas 100. Periode studi terdiri dari periode estimasi dan periode acara yang berlangsung dari 30 Desember 2016 hingga 15 Maret 2017. Event study digunakan untuk menguji seberapa cepat pasar bereaksi terhadap informasi baru. Hasil penelitian menunjukkan bahwa pasar bereaksi positif pada hari kedua setelah pengumuman. Hasil ini sejalan dengan Teori Signaling di mana pasar akan cenderung menafsirkan peristiwa pengumuman investasi dari King Salman sebagai sinyal bahwa Indonesia memiliki prospek ekonomi yang baik di masa depan. Sinyal ini akan mempengaruhi aktivitas di pasar modal yang ditandai oleh pergerakan harga saham.

2. Penelitian yang dilakukan oleh Murdifi, Nur Hidayati dan Juanidi (2018) dengan judul "Efek Peristiwa Politik Terhadap Kinerja Pasar Modal Indonesia (Even Study Pada Vonis Yang Diberikan Kepada Basuki Tjahaja Purnama)". Penelitian ini bertujuan untuk mengetahui perbedaan Abnormal Return sebelum dan sesudah ditetapkan vonis Ahok pada tanggal 09 Mei 2017. Alat uji yang digunakan adalah Paired Sampel t-test . Berdasarkan hasil analisis terhadap studi peristiwa (event study) terhadap vonis Ahok menunjukkan bahwa aktivitas di pasar modal terhadap harga saham yang memiliki kapitalisasi pasar tinggi, yaitu dengan menghitung nilai $t$ sebelum dan sesudah ditetapkan vonis Ahok pada tanggal 09 Mei 2017. Hasil penelitian ini menunjukkan bahwa terdapat abnormal return signifikan yang dapat 
dinikmati oleh investor dengan $\mathrm{t}<0,05$. Hal ini menunjukkan bahwa terdapat perbedaan sebelum dan sesudah peristiwa. Sehingga dapat disimpulkan bahwa peristiwa ditetapkannya vonis Ahok pada tanggal 9 Mei 2017 dengan menggunakan indikator abnormal return mengandung informasi negatif, sehingga investor di pasar modal bereaksi).

3. Penelitian yang dilakukan oleh Siti Wardani Bakri Katti (2018) dengan judul "Pengaruh Peristiwa Politik (Pemilu Presiden dan Pengumuman Susunan Kabinet) Terhadap Saham Sektor Industri Di Bursa Efek Indonesia". Peristiwa politik merupakan salah satu risiko non-ekonomi yang dapat mempengaruhi keputusan investor untuk berinvestasi di pasar modal. Tujuan penelitian ini untuk mengetahui reaksi dan perbedaan abnormal return saham sektor industri di Bursa Efek Indonesia (BEI) antara sebelum dan sesudah peristiwa politik (pemilihan umum presiden dan pengumuman susunan kabinet). Pemilihan perusahaan sektor industri sebagai objek penelitian berdasarkan pemikiran bahwa sektor industri merupakan sektor utama yang mendorong perdagangan saham di BEI. Penelitian ini menggunakan metode event study untuk mengukur reaksi pasar terhadap peristiwa politik nasional. Dalam penelitian ini digunakan data Indeks Harga Saham Gabungan (IHSG) serta data perdagangan saham harian pada sektor industri. Berdasarkan hasil seleksi sampel menggunakan metode purposive sampling, sampel dalam penelitian sebanyak 40 perusahaan. Hasil penelitian menunjukan bahwa ada abnormal return di seputar peristiwa politik nasional, namun tidak ada perbedaan Average Abnormal Return (AAR) sebelum dan sesudah peristiwa politik. Hal ini menunjukkan prediksi dan informasi yang diterima oleh pelaku pasar saham relatif sama.

4. Penelitian yang dilakukan oleh Ruffino Ruven, Achsani Noer Azam dan Syarifuddin Ferry (2019) dengan judul " Impact of Presidental Election on Indonesia Capital Market: An Event Study Analysis". Peristiwa politik seperti pemilihan presiden Indonesia pada tahun 2014, pemilihan presiden AS pada tahun 2016, dan pemilihan presiden Indonesia pada tahun 2019 diperkirakan akan berdampak pada kinerja pasar modal Indonesia. Ini akan berdampak besar pada dinamika indeks harga pasar saham yang menjadi sangat fluktuatif karena investor akan merespons peristiwa itu. Tujuan dari penelitian ini adalah untuk menganalisis perbedaan abnormal return yang ditemukan di Indonesia Composite Index dalam 5 hari dan 10 hari sebelum dan sesudah acara. Metodologi studi peristiwa digunakan untuk mengevaluasi dampak pemilihan presiden terhadap pasar modal Indonesia. Penelitian ini juga mengevaluasi efek signifikan dari setiap peristiwa menggunakan uji sampel berpasangan. Hasil penelitian ini memberikan opsi alternatif bagi investor untuk mengambil keputusan pada saat acara serupa di masa depan.

Berdasarkan tinjauan teoritis dan hasil penelitian terdahulu yang relevan maka kerangka konseptual dari penelitian ini dapat digambarkan sebagai berikut: 


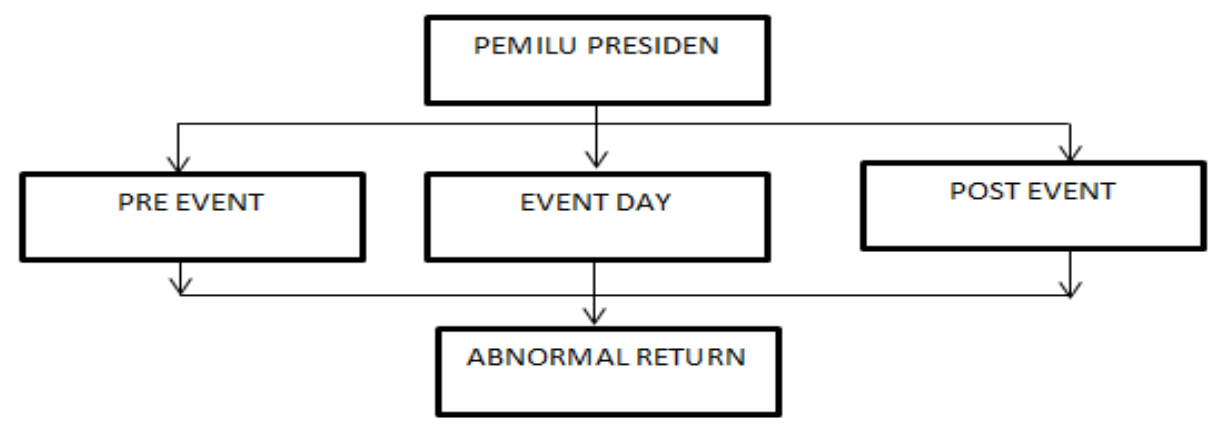

Gambar

Kerangka Konseptual

Maka berdasarkan kerangka konseptual diatas hipotesis yang diajukan adalah :

$\mathrm{H}_{\mathrm{o}} \quad$ : Tidak ada perbedaan return sebelum dan sesudah pemilihan Presiden

$\mathrm{H}_{\mathrm{a}} \quad$ : Ada perbedaan return sebelum dan sesudah pemilihan Presiden

\section{METODE}

\section{Populasi dan Sampel}

Reaksi pasar modal akan dilihat dari salah satu indeks yang ada di Bursa Efek Indonesia. Indeks yang akan digunakan adalah indeks LQ 45. LQ 45 yaitu indeks yang terdiri atas 45 saham pilihan dengan mengacu pada dua variabel yaitu likuiditas perdagangan dan kapitalisasi pasar. Saham-saham yang masuk LQ 45 merupakan sahamsaham yang memiliki likuiditas tinggi dan kapitalisasi pasar yang dijajaran teratas. Sehingga populasi dari penelitian ini adalah seluruh perusahaan yang masuk ke dalam LQ 45 selama periode pengamatan penelitian. Metode sampling yang digunakan adalah purposive sampling yaitu teknik mengambilan sampel berdasarkan kriteria tertentu. Kriteria yang ditentukan adalah perusahaan yang termasuk LQ 45 dalam periode pengamatan penelitian yang memiliki data-data keuangan lengkap yang dibutuhkan dalam penelitian ini.

\section{Desain Penelitian}

Desain penelitian ini merupakan penelitian studi peristiwa (event study). Event Study merupakan penelitian yang meneliti dampak dari suatu peristiwa terhadap suatu variabel. Event yang digunakan dalam penelitian ini pemilihan Presiden RI periode 2019-2024 yang dilaksanakan tanggal 17 April 2019. Dampak yang dimaksud kemudian akan dilihat dari apakah terdapat perbedaan variabel tersebut sebelum dan sesudah peristiwa tersebut terjadi. 


\section{Jenis dan Sumber Data}

Jenis data yang digunakan dalam penelitian ini adalah data sekunder. Data sekunder adalah data Metode pengumpulan data dalam penelitian ini menggunakan metode dokumentasi. Metode dokumentasi dilakukan untuk mengumpulkan data sekunder dari berbagai sumber. Dalam penelitian ini data sekunder yang diperlukan adalah data harga saham yang diperoleh dari yahoo.finance.com.

\section{Definisi Operasional Variabel dan Skala Pengukurannya}

Reaksi pasar modal terhadap peristiwa politik akan dilihat dengan menggunakan variabel abnormal return. Abnormal return adalah return yang melebihi perkiraan pergerakan pasar. Berikut definisi dan opersionalisasi variabel yang digunakan dalam penelitian ini:

Tabel

Operasionalisasi Variabel

\begin{tabular}{|c|c|c|c|c|}
\hline No. & Variabel & Definisi & Rumus & Skala \\
\hline 1. & $\begin{array}{c}\text { Abnormal } \\
\text { Return (AB) }\end{array}$ & $\begin{array}{c}\text { Return yang melebihi } \\
\text { perkiraan pergerakan pasar }\end{array}$ & $\begin{array}{c}\mathrm{AB}= \\
\text { Actual Return- } \\
\text { Expected } \\
\text { Return }\end{array}$ & Nominal \\
\hline 2. & $\begin{array}{l}\text { Actual } \\
\text { Return } \\
\text { (AR) }\end{array}$ & $\begin{array}{l}\text { Return yang telah terjadi } \\
\text { (return aktual) yang dihitung } \\
\text { berdasarkan data historis }\end{array}$ & $\begin{array}{c}\mathrm{AR}= \\
\frac{\mathrm{Pt}-\mathrm{Pt}-1}{\mathrm{Pt}-1}\end{array}$ & Nominal \\
\hline 3. & $\begin{array}{l}\text { Expected } \\
\text { Return } \\
\text { (ER) }\end{array}$ & $\begin{array}{l}\text { Return yang diharapkan akan } \\
\text { diperoleh oleh investor di } \\
\text { masa mendatang. }\end{array}$ & $\mathrm{ER}=$ & Nominal \\
\hline
\end{tabular}

Sumber : Dari berbagai sumber

\section{Teknik Analisis Data}

Reaksi pasar modal akan dilihat dari apakah terdapat perbedaan variabel abnormal return sebelum dan sesudah masa pemilihan umum presiden. Sehingga untuk itu dalam penelitian ini mengunakan uji beda. Uji paired sample t test merupakan bagian dari uji hipotesis komparatif atau uji perbandingan. Uji ini bertujuan untuk mengetahui apakah terdapat perbedaan rata-rata dua sampel (dua kelompok) yang saling berpasangan atau berhubungan 
Data dalam penelitian ini adalah data abnormal return. Data average abnormal return (AAR) sebelum dan sesudah pemilu umum presiden adalah sebagai berikut:

Tabel

Deskriptif ARR Saham LQ45

Sebelum dan Sesudah Peristiwa Pemilihan Umum Presiden

\begin{tabular}{|l|r|c|c|c|}
\hline & \multicolumn{1}{|c|}{$\mathrm{N}$} & Minimum & Maximum & Mean \\
\hline AAR SEBELUM- & 10 & -.01212136 & .03320594 & .0022367535 \\
PEMILU & & & & \\
AAR SESUDAH- & 10 & -.01410621 & .01507132 & .0000108756 \\
PEMILU & 10 & & & \\
Valid N (listwise) & & & \\
\hline
\end{tabular}

Sumber : Output SPSS

Berdasarkan tabel di atas maka terlihat data rata-rata abnormal return dalam penelitian ini. Rata-rata abnormal return yang dimaksud adalah rata-rata abnormal periode 10 hari sebelum dan 10 hari sesudah peristiwa Pemilihan Umum Presiden. Bisa terlihat dari tabel diatas rata-rata abnormal return 10 hari sebelum peristiwa Pemilihan Umum Presiden bernilai yaitu 0,0022367535\%. Sementara itu rata-rata abnormal return 10 hari sesudah peristiwa Pemilihan Umum Presiden adalah 0,0000108756\%. Dengan demikian bisa terlihat bahwa ada penurunan abnormal return sesudah peristiwa Pemilihan Umum Presiden walaupun hanya sedikit. Semakin kecil abnormal return semkain menunjukan reaksi pasar dan investor cenderung sama. Sementara itu nilai terendah dari rata-rata abnormal return sebelum peristiwa Pemilihan Umum Presiden mencapai $0,01212136 \%$ dan nilai terrendah dari rata-rata sesudah peristiwa Pemilihan Umum Presiden $\quad-0,01410621 \%$. Nilai yang negatif menunjukan bahwa actual return lebih kecil dibandingkan dengan expected return. Sementara itu nilai tertinggi rata-rata abnormal return sebelum peristiwa Pemilihan Umum Presiden mencapai 0,03320594\% dan nilai tertinggi rata-rata abnormal return sesudah peristiwa Pemilihan Umum Presiden mencapai 0,01507132\%.

Karena data terdistribusi normal maka uji beda menggunakan statistic parametric. Uji beda yang digunakan adalah uji paired sample $t$ test.

Secara teoritis peristiwa-peristiwa tertentu yang relevan mampu mempengaruhi pasar modal atau minimal pasar modal akan bereaksi. Peristiwa politik yang menjadi perhatian atau melibatkan masyarakat secara umum biasanya mampu mempengaruhi kestabilan politik suatu Negara atau wilayah. Jika kemudian peristiwa politik direspon positif oleh masyarakat makan akan menciptakan suasana politik yang kondusif. Suasana politik yang kondusif akan mendorong para investor untuk berinvestasi karena tidak ada kekhawatiran akan kondisi politik kedepan. Tetapi jika peristiwa politik tersebut direspon negatif oleh masyarakat pada umumnya maka akan menyebabkan kondisi politik yang kurang kondusif dan ini tidak akan mendorong investor untuk berinvestasi.

Salah satu peristiwa politik yang dianggap mampu mempengaruhi pasar modal adalah peristiwa pemilihan Presiden. Harus diakui jika terjadi pergantian kepemimpinan dalam suatu Negara sangat berpotensi akan terjadi perubahan di segala sektor. Hal ini 
dikarenakan setiap pemimpin mempunyai kebijakan masing-masing sehingga pemimpin baru akan sangat mungkin berbeda kebijakannya dengan pemimpin sebelumnya. Kondisi ini akan mempengaruhi respon para pelaku di pasar modal. Dimasa pemilihan presiden karena belum ada kepastian beberapa pelaku pasar modal memanfaatkan kondisi untuk berspekulasi sehingga potensi terjadinya abnormal return pada masa pemilihan presiden cukup tinggi.

Sementara itu hasil penelitian menunjukan bahwa tidak ada perbedaan return sebelum dan sesudah peristiwa pemilihan presiden. Tidak adanya perbedaan return sebelum dan seduah peristiwa pemilihan Presiden mengindikasikan perilaku investor terkait keputusan investasi di pasar modal sama saja. Hasil penelitian ini tidak sesuai dengan teori. Hal ini dimungkinkan terjadi karena peristiwa pemillihan Presiden belum secara jelas menggambarkan kepastian kepemimpinan masih dalam tahapan pemilihan. Pada periode pemilihan Presiden para investor sepertinya tidak bisa memprediksi siapa Presiden yang akan terpilih mengingat persaingan antar para peserta sangat ketat, ini bisa dilihat dari suasana politik yang memanas serta situasi dan kondisi dimana para peserta di pemilihan Presiden memiliki peluang yang sama-sama besar. Kondisi seperti ini berpotensi mendorong investor untuk menunggu sebelum mengambil keputusan akan kepastian siapa Presiden terpilih. Karena periode pengamatan dalam penelitian ini hanya sebelum dan sesudah pelaksanaan pemilihan Presiden tetapi belum masuk ke periode pengumuman hasil pemilihan Presiden. Hal ini yang kemudian berpotensi menyebabkan respon para pelaku di pasar modal masih sama.

Hasil penelitian yang menunjukan tidak terdapat perbedaan return sebelum dan sesudah peristiwa pemilihan Presiden menunjukan bahwa peristiwa politik tidak mampu mempengaruhi kondisi pasar modal. Hasil penelitian ini konsisten dengan penelitian terdahulu yang relevan yang dilakukan oleh Siti Wardani Bakri Katti (2018), penelitian ini dilakkukan untuk mengetahui reaksi dan perbedaan abnormal return saham sektor industri di Bursa Efek Indonesia (BEI) antara sebelum dan sesudah peristiwa politik (pemilihan umum presiden dan pengumuman susunan kabinet). Hasil penelitian menunjukan tidak ada perbedaan Average Abnormal Return (AAR) sebelum dan sesudah peristiwa politik. Selain itu hasil penelitian juga konsisten dengan penelitian terdahulu relevan lainnya yaitu penelitian yang dilakukan oleh Ruffino Ruven, Achsani Noer Azam dan Syarifuddin Ferry (2019). Tujuan dari penelitian ini adalah untuk menganalisis perbedaan abnormal return yang ditemukan di Indonesia Composite Index dalam 5 hari dan 10 hari sebelum dan sesudah acara. Metodologi studi peristiwa digunakan untuk mengevaluasi dampak pemilihan presiden terhadap pasar modal Indonesia. Penelitian ini juga mengevaluasi efek signifikan dari setiap peristiwa menggunakan uji sampel berpasangan. Hasil penelitian ini memberikan opsi alternatif bagi investor untuk mengambil keputusan pada saat acara serupa di masa depan.

Tetapi hasil penelitian tidak konsisten dengan penelitian terdahulu yang relevan yaitu penelitian yang dilakukan oleh Ima Kristina Yulita (2017). Penelitian ini meneliti apakah terdapat abnormal return sebagai indikator reaksi pasar pada hari-hari menjelang 
pengumuman keputusan investasi Salman King. Hasil penelitian menunjukkan bahwa pasar bereaksi positif pada hari kedua setelah pengumuman. Hasil ini sejalan dengan Teori Signaling di mana pasar akan cenderung menafsirkan peristiwa pengumuman investasi dari King Salman sebagai sinyal bahwa Indonesia memiliki prospek ekonomi yang baik di masa depan. Sinyal ini akan mempengaruhi aktivitas di pasar modal yang ditandai oleh pergerakan harga saham. Dan penelitian terdahulu yang relevan lainnya yang tidak konsisten dengan hasil penelitian ini adalah penelitian yang dilakukan oleh Murdifi, Nur Hidayati dan Juanidi (2018) . Penelitian ini bertujuan untuk mengetahui perbedaan Abnormal Return sebelum dan sesudah ditetapkan vonis Ahok pada tanggal 09 Mei 2017. Hal ini menunjukkan bahwa terdapat perbedaan sebelum dan sesudah peristiwa ditetapkannya vonis Ahok pada tanggal 9 Mei 2017.

\section{PENUTUP}

Berdasarkan hasil analisa dan pembahasan maka dapat disimpulkan, sebagai jawaban dari perumusan masalah yang ada bahwa pasar modal tidak ada reaksi pasar modal atas peristiwa politik yang terjadi yaitu peristiwa pemilihan Presiden. Hal ini ditunjukan dengan tidak adanya perbedaan return sebelum dan sesudah peristiwa pemilihan Presiden.

Berdasarkan hasil penelitian maka saran yang bisa diberikan untuk penelitian selanjutnya adalah (1) Memperpanjang periode pengamatan untuk memastikan apakah terdapat reaksi pasar modal atas peristiwa politik terjadi, (2) mengganti peristiwa politik lainnya yang berpotensi mampu mempengaruhi kinerja pasar modal seperti peristiwa pengumuman Presiden terpilih, peristiwa ini menunjukan kepastian kepemimpinan sehingga berpotensi para pelaku pasar modal lebih jelas untuk membuat keputusan investasi.

\section{DAFTAR PUSTAKA}

Cahaya Nugrahani Agung Nugroho Jati. 2017. Reaksi Pasar Modal Syariah Indonesia Terhadap Peristiwa ( Event Study pada Peristiwa Kemenangan Donald Trump Sebagai Presiden Amerika Serikat Ke - 45), Kiat BISNIS Volume 6 No. 5 Juni, 450-460.

Jogiyanto. 2010. Teori Portofolio dan Analisis Investasi, Edisi Ketujuh. Yogyakarta: BPFE.

Katti, Siti Wardani Bakri .2018.Pengaruh Peristiwa Politik (Pemilu Presiden dan Pengumuman Susunan Kabinet) Terhadap Saham Sektor Industri Di Bursa Efek Indonesia, Capital, Volume 1, Nomor 2, Maret : 125-134.

Murdifi, Nur Hidayati dan Juanidi . 2018. Efek Peristiwa Politik Terhadap Kinerja Pasar Modal Indonesia. (Even Study Pada Vonis Yang Diberikan Kepada Basuki Tjahaja Purnama), E-JRA Vol. 07 No. 06 Agustus: 50-61

Rahmawati , Ika Yustina, Tiara Pandansari . 2016. Reaksi Pasar Modal Dari Dampak Peristiwa Bom Plaza Sarinah Terhadap Abnormal Return Perusahaan LQ 45 
Yang Terdaftar Di BEI. Riset Akuntansi dan Keuangan Indonesia, 1(2), : 126133

Ruven, Ruffino Achsani Noer Azam dan Syarifuddin Ferry. 2019. Impact of Presidental Electiob on Indonesia Capital Market : An Event Study Analysis, RJOAS, 7(91), July 2019: DOI 10.18551/rjoas.2019-07.18, $177-185$

Saraswati, Ni Made Ayu Windika, Ketut Mustanda. 2018. Reaksi Pasar Modal Indonesia Terhadap Peristiwa Pengumuman Hasil Perhitungan Suara Pemilihan Umum dan Pelantikan Presiden Amerika Serikat, E-Jurnal Manajemen Unud, Vol. 7, No. 6,: 2971-2998

Sugiyono.2017.Metode Penelitian Manajemen. Bandung. Alfabeta

Tjiptono Darmadji dan Hendy M. Fakhruddin. 2012. Pasar Modal Di Indonesia. Edisi Ketiga, Jakarta.: Salemba Empat.

Trisnawati, Fenny. 2011. Pengaruh Peristiwa Politik Terhadap Perubahan Harga Saham., Pekbis Jurnal, Vol.3, No.3, November: 528-535.

Yulita , Ima Kristina .2017. Reaksi Pasar Modal Terhadap Pengumuman Keputusan Investasi Raja Salman di Indonesia, Jurnal Penelitian. Volume 21, No. 1, Mei, hlm. 95-106.

www.idx.co.id

www.yahoofinance.com 